\title{
A Study on the Impact of the Short Selling Ban on FIBS
}

\section{Simon Grima ${ }^{1}$, Stephen Sammut ${ }^{2}$ \\ Abstract:}

In this paper we investigate how the short selling ban affected stock markets in France, Italy, Belgium and Spain and whether the required response was really achieved and reflected in the market. Although some argue that the short selling ban was needed for the market to get back on its feet, others argue that short selling is a tool that improves market efficiency and banning such trading strategy might lead to detrimental effects on the market.

Therefore, the purpose of this study was to show whether the short selling ban had a positive or negative effect, both in the short-term and long-term, on the financial markets. Moreover, to determine whether short selling is an effective tool and whether it really drives the stock prices down when the financial markets are going through bad moments. Consequently, uncover whether the short selling ban has had a permanent impact on the financial markets and whether it really had an effect on the FIBS. To do this we used market data and a selection of stock returns, which included banned stocks in the FIBS financial markets and non-banned financial stocks from non-FIBS before, during and after the short-selling ban in August 2011.

It was found that the short selling ban led to higher volatility in the FIBS countries and also had a spill over effect on non-FIBS countries. Furthermore, the impact of the short selling ban on volatility was only deemed to be for a short-term period, with the exception of Spain. Also, the short selling ban slowed down price discovery in Belgium, France and non-FIBS countries, whereas the short selling ban did not affect Spain and Italy. Furthermore, all countries including the non-FIBS countries illustrated a better price discovery position after the ban was lifted; therefore the short selling ban only had a short-term impact on price discovery. Moreover, there was a long-term positive effect on prices with improvement in stock market prices for all FIBS countries with a positive impact on non-FIBS countries. However, liquidity in all FIBS and non-FIBS countries suffered a short-term negative impact.

Keywords: Short Selling Ban, FIBS, Non-FIBS, Price Discovery, Volatility, Liquidity, Financial Stock Prices, Pre-Ban Period, Ban Period, Post-Ban Period.

JEL classification: G01, G15.

\footnotetext{
${ }^{1}$ simon.grima@um.edu.mt University of Malta, Head Insurance Department, Original scientific paper UDK.

${ }^{2}$ ssammut.vfs@bov.com University of Malta, Department of Banking and Finance.
} 


\section{Introduction}

Short selling is considered to be a risky type of trading strategy. This due to the fact that some professional investors use a trading strategy known as naked short selling, whereby the investor does not borrow the stock or insure the feasibility of borrowing the stocks before short selling them. Furthermore, it is widely known that some investors will do anything in order to have an advantage over their competitors and therefore they might make use of false rumours in order to make them believe a false story and therefore artificially try to manipulate the price of a stock. (Securities and Exchange Commission, 1999).

Regulators have in fact, on several occasions highlighted short selling to be one of the factors contributing to the financial crisis. They were convinced that short selling activity was a factor of instability in the financial markets and the European Markets and Securities Commission (ESMA) decided to impose, on August 2011, a ban on France, Italy, Belgium and Spain (FIBS) stock markets (Handjani, Ali, 2012).

Stock exchange regulators argued that short selling activity led to sudden price declines in the stock market, which led to higher volatility in the market and lower liquidity. However, on the other hand, other analysts and theorists suggest that short selling does not really lead to such repercussions (Avgouleas, Emilios, 2010). The shares of 56 companies were subject to the short selling ban, of which 10 companies are domiciled in France, 28 in Italy, 4 in Belgium and 14 in Spain.

In 2011, the European stock markets saw a huge decline in its stock prices, where in the FIBS the most notable price declines were between July and August, with the BEL20 (Belgian stock index), CAC40 (France's stock index), FTSE/MIB (Italian stock index) and IBEX (Spanish stock index) declining by approximately $8 \%, 7.8 \%$, $7.5 \%$ and $7.9 \%$ respectively. ${ }^{3}$

Furthermore, the comparison between the financial stocks and the market's stock as a whole indicate that the decline was even bigger when it came to financial stocks. When looking at the financial stocks of the FIBS, the results show that in France the decline in the CAC financial stocks in July and August 2011 was $12.61 \%$ and $18.55 \%$ respectively. On the other hand, in Belgium the decline in financial stocks was similar to the decline in the market as a whole with approximately an $8 \%$ decline in July and August. In Italy, the FTSE/MIB financial stocks were close to $8 \%$ in July, however the financial stocks suffered a $15.57 \%$ decline in August. Furthermore, in Spain the IBEX financial stocks were close to the market's stocks with $7.04 \%$ and $9.47 \%$ in July and August respectively. However, the study can conclude that there was a higher devaluation in financial stocks compared to the market as a whole, which makes the analysts question such a discrepancy.

\footnotetext{
${ }^{3}$ Data collected from: [http://www.euroinvestor.com/markets/stocks/europe] [viewed on: 25/10/14]
} 
Another interesting observation is that there was a $29.3 \%$ decline in financial stocks of the FIBS compared to the $20.6 \%$ decline in financial stocks in other European countries. $^{4}$

As noted in this study, short selling is a controversial subject amongst various analysts and researchers due to the impact it has on the liquidity, volatility and market prices. Moreover, although many studies have been carried out on short selling bans in general and during the 2008 recession, few researchers have studied the impact of the 2011 short selling ban on the FIBS. Therefore, we aim to evaluate how the market in the FIBS faired during the 2011 short selling ban and the effects it had on such markets. We analyse whether short selling bans really have a negative effect on price discovery and whether price discovery tends to slow down when there is some negative news. Basically, we investigate whether stock discovery is affected negatively by short selling bans. We feel that a study of this kind will be of benefit to both academics and regulators in search of solutions to the risks the European economies are facing.

\section{$1.1 \quad$ Research Questions}

We based our studies on answering the following research questions and the following hypothesis:

a. Did the financial stocks perform differently in terms of returns prior to the ban? - here we seek to understand whether the financial stocks where performing differently prior to the ban as compared to financial stocks performing during normal market environment. If the financial stocks performed differently, then the effects of the short selling ban on financial stocks would raise another question, i.e. whether the ban really had an impact or whether it was due to the financial stocks not performing normally that such repercussions occurred during and after the short selling ban.

b. How did FIBS financial stocks compare to the non-FIBS financial stocks during the short selling ban? - here we seek to determine how the banned financial stocks in the FIBS faired as compared to the non-banned financial stocks in non-FIBS countries. This to show whether the short selling ban has a positive impact or not. However it should be noted that different countries may have different market scenarios to trade in so certain effects could be unrelated to the short selling ban.

c. What was the impact both in the short-term and long-term of the short selling ban on the FIBS' liquidity, volatility and prices? - here, we seek to determine how the short selling ban effected the FIBS' liquidity, volatility and prices and whether the effects where only for a short period or whether the effects were of permanent, or long-term nature.

\footnotetext{
${ }^{4}$ Data collected from: [http://www.investing.com/indices] [viewed on: 25/10/14]
} 


\section{$1.2 \quad$ Hypothesis}

H0:As suggested by Beber and Pagano (2010) and Boehmer et. al (2008), short selling ban in the FIBS, as well as the short selling ban in general, does not contribute to market and stock price stabilisation but leaves stock prices unaffected or even worse have the opposite effect on the stock market regulators' intentions to stabilise the market. The study's results should indicate that the higher the average daily number of transaction, the higher the market liquidity. The latter therefore suggests that there is no major imbalance between supply and demand.

H1:Short selling ban in the FIBS, as well as the short selling ban in general, will contribute to market and stock price stabilisation.

\section{Literature Review}

Concerned with the impacts of the European Sovereign debt crisis on their respective countries, European Regulators, conducted stress tests on European banks. This led to a temporarily ban on short-selling transactions of financial stocks in France, Italy, Belgium and Spain (FIBS). Several researchers have tried to test and provide evidence for the impact of short selling both on the law of one price (no arbitrage opportunities in the markets) and on the financial markets as a whole (Gagnon, L., Witmer, J., 2009).

\subsection{Impact of Short Selling Restrictions on Liquidity}

Beber and Pagano (2011) and Boehmer et al. (2012), in their studies, found that short selling bans have a negative effect on liquidity. The former, concluded that short selling bans have a detrimental effect on the market's liquidity. They question the regulator's decision in the U.S. to ban short selling during a time where liquidity was fundamental to the markets. They highlight that the median bid-ask spread was larger during the short selling ban as compared to bid-ask spreads outside the short selling ban period. Noting, that the bid-ask spread was on average 2.27 times larger as compared to the pre-ban period and over 3 times larger as compared to the postban period, with Italy's short selling ban having the most devastating negative effect on the market's liquidity.

In both studies it was found that short selling bans increase the end of day bid-ask spreads in the financial markets and therefore implying that liquidity suffers when short selling is banned. They also highlight the fact that bid-ask spreads can be viewed as an illiquidity measure where the wider the spread, the less liquid the stock is. Moreover, they note that even after the ban was lifted, there was illiquidity. However the reason could be because the market's volatility remained very high.

Fotak et al. (2010) agreed with Boehmer et al.'s (2012) findings, that short selling bans tend to have an adverse effect on liquidity. However they look at naked short 
sales (short selling without borrowing). They, highlight the fact, that naked short sales have the same impact on the market as covered short sales during trading time. Moreover, they note that an increase in naked short selling will lead to a reduction in spreads and therefore an increase in liquidity. Furthermore, Fotak et al. (2010) argue that naked short selling leads to lower order imbalances (reducing the gap between excess supply and demand when major news hits the markets), and therefore improving the liquidity.

These views are shared by other researchers namely Gagnon and Witmer (2009) who looked at the Canadian markets short selling bans; Battalio and Schultz (2010) who reviewed the U.S. stock market during the short selling ban and found that the spreads resulted in liquidity costs amounting to over $\$ 600$ million; Marsh and Payne (2010), who looked into the U.K. markets finding that financial stocks had a greater impact on liquidity as compared to non-financial stocks in the U.K. markets.

On the other hand, Jones and Lamant (2002) did not agree with the researchers above. They argued that during the Great Depression in the U.S., when in 1932 there was a requirement that brokers should secure written authorisation before lending a shares, reduced liquidity. However, the 1938 requirement, which required short selling strategies, only to be executed if there was an increase on the stock, resulted in increased liquidity (Beber and Pagano, 2011). Charoenrook and Daouk (2005) concur with this finding and note that short selling restrictions in 111 countries they studied correlate with greater market liquidity.

\subsection{Impact of Short Selling Restrictions on Price Discovery}

Diamond and Verrecchia (1987) concluded that market restrictions tend to slow down price discovery and therefore result in an increase in the bid-ask spreads. Furthermore, the study concludes that short selling restrictions tend to slow the price more in bear markets as compared to the bull markets.

Although, Miller (1977) agrees to this, but contrary to Diamond and Verrecchia (1987) argues that short selling restrictions tend to move the price upwards, leading to 'overpricing' of the stock.

Harrison and Kreps (1978) also conclude that short selling restrictions tend to slow down price discovery in the markets. Harrison and Kreps, however assume that all investors have the same information and no inside information is known to investors.

Biais et al. (1999) conclude similarly, that in the French market when market restrictions are imposed good information about the market tends to be reflected faster than bad news on the market. 
Bris et al. (2003) analysed the stock of 47 equity markets around the world and came up with two conclusions about the impact of short selling restrictions on price discovery. The first conclusion was that short selling does in fact help price discovery in the stock markets. The second conclusion was that short selling might lead to greater price declines in individual stocks, hence concluding that short selling constraints have little or no impact on severe price declines in the markets.

Boehmer and $\mathrm{Wu}$ (2010) suggest that being informed does not mean that the market prices will immediately reflect the information being given to the traders involved. On the contrary, traders who receive information would want to keep that information for themselves and not leak it into the market. They suggest that when short selling is allowed on the market, market prices tend to react faster to new public information, thus concluding that short selling can be a marketing strategy that helps the market to reflect price information. Furthermore, they suggest that short selling leads to smaller pricing errors and therefore price discovery is reflected faster in the market. However, when analysing the impact of short selling restrictions on price discovery, they concluded that restrictions tend to hinder price discovery in the market.

Saffi and Sigurdsson (2011) studied over 25 countries over the period of three years in order to analyse how short selling restrictions affect price efficiency. They concluded that short selling restrictions do not lead to price instability or high negative returns on the affected stocks.

Beber and Pagano (2011) also analyse the impact of the 2008 short selling ban in the U.S. on price discovery. They concluded that short selling restrictions tend to slow down price discovery especially when bad news is announced on the market. Beber and Pagano's (2011) conclusions are in line with Diamond and Verrecchia's (1987) conclusions, that short selling restrictions tend to slow down price discovery more in the bear market as compared to the bull market.

When testing whether it is a good idea for regulators to impose short selling restrictions in order to limit the activity of traders in bearish markets and therefore slowing down price discovery more in bearish markets as compared to bullish markets, Beber and Pagano (2011) found that, short selling bans slow down price discovery more in bearish markets as compared to bullish markets.

\subsection{Impact of Short Selling Restrictions on Prices and Returns}

Jones and Lamont (2001) conclude that stocks tend to be overpriced when short selling bans are imposed on stock markets. They find that some stocks tend to be too expensive to be shorted; therefore they are considered to be overpriced in the market and yield lower returns. 
Chang et al. (2007) conclude similarly after analysing the Hong Kong stock markets and notes that this impact happens especially for individual stocks. However, in their analysis they also consider the investors' opinion about the stock and conclude that the more different the investors' opinions are the more overvalued the stocks are.

Similar conclusions were reached by Autore et al. (2011), who focused their studies on the illiquidity shock and the overpricing of the stocks and Lobanova et al. (2010), who focused their studies on the impact of the short-selling ban in the U.S. on liquidity, volatility and market efficiency and found that during the 2008 short selling restriction in the U.S. returns on banned stocks reduced as compared to other periods.

Diether et al. (2007) tested whether short sellers are able to make future decisions about their stocks based on new laws enacted by the SEC in 2005. They conclude that short sellers tend to be more active in the market when stock prices increase and they tend to short less when stock market prices tend to decrease. The latter shows that Diether et al. (2007) come to the same conclusion as Biais et al. (1999), that short sellers and traders in general tend to react more to bad news than good news. However, on the other hand, Diether et al. (2007), do not agree with most researchers that the larger the difference between the investors' opinions, the more overpriced the stocks are. In fact, Diether et al. (2007), state that as uncertainty and difference of opinions amongst investors grows larger, the more short selling activities tend to be executed, therefore having a more efficient market.

Boehmer et al. (2012) agree with Diether et al. 's (2007) reasoning and conclude that short selling restrictions do not have any effect on stock market prices. They studied banned stocks both during the ban, before and after the ban on those stocks. They concluded that there were no exaggerated price changes when comparing the pre-ban period and the ban period on the stocks involved, noticing that banned stocks were subject to underperformance in the stock market during the ban. Boehmer et al. (2007) analysed the abnormal returns of the original banned stocks as compared to the cumulative returns to similar never banned stocks. They concluded that the day after the ban was imposed, the banned stocks made an average of $6.68 \%$ returns as compared to the $3.48 \%$ for the never banned stocks. Boehmer et al. (2007) also state that such a difference could be permanent.

However, the abnormal returns made by the affected institutions could be due to the Troubled Asset Relief Program (TARP) announcement (a program that was intended to strengthen market stability and financial institutions) on that same date, on which the short selling restriction was imposed. They also found that the day the ban was enacted on them the average excess return on the banned stocks was very close to zero. Boehmer et al. (2007), suggest that the reason for a close to zero average excess return could be that the SEC's intention to boost the share prices by imposing the short selling ban is outweighed by the negative price effects of the short selling restriction. 
Furthermore, Beber and Pagano (2011) also conclude that short selling restrictions do not lead to overpricing of stocks in the markets and decline again when the restriction is no longer imposed. They, in fact find some overpricing in the U.S. data stock market, which could be due to the TARP announcement. However when analysing other countries they do not find any overpricing of the stocks when a ban is imposed but rather no changes in the stock prices.

\subsection{Impact of Short Selling Restriction on Volatility}

Charoenrook and Daouk (2005) concluded that short selling leads to less volatility in aggregate stock returns and decline the claims that short selling leads to higher market volatility.

Bris et al. (2003) study the effect of short selling restrictions on volatility by calculating the average standard deviation of individual stock returns and use its logs, in order to arrive at the stocks' real value. They conclude that short selling restrictions do lead to higher volatility in the stock market returns. They also notice that volatility is even higher is less-developed countries as compared to countries with more prestigious governments. These findings are similarly concurred to by Beber and Pagano (2011) and Boehmer et al. (2012).

\section{Methodology}

Using non-probability judgmental sampling we chose 52 banned stocks and 17 nonbanned stocks. The main demographic variable for the study was the weekly excess returns of the relevant FIBS (France, Belgium, Italy and Spain) and non-FIBS (Germany, Austria, Greece and the Netherlands) financial stocks pre, during and post the ban between August 2011 and February 2012. The total frequency of the demographic variable (the weekly excess returns) amounted to 8,112 observations for the 52 banned stocks and 2,652 observations for the 17 non-banned stocks. Data was collected to measure liquidity, volatility and prices before, during and after the ban.

One of the main reasons why non-probability judgmental sampling was used for this study is due to the accessibility of the stocks and the research requiring a very specific group, where specific financial stocks that were subject to the short selling ban were needed. Furthermore, some of the financial stocks required for the study had either merged or went bankrupt during the period that the study was be carried out.

Furthermore, when sampling the non-FIBS stocks, non-probability, judgmental sampling was chosen due to the fact that they were influential countries during the period the study was carried out. Furthermore, other countries such as Norway were not selected due to the stock prices being in their home currency not in Euro. The 
stocks gathered were then identified from Thomson Reuters and downloaded using the add-on onto Ms Excel.

In order to analyse what impact the short selling ban had on liquidity in FIBS countries, the average daily number of transactions was deemed to be the most appropriate measurement tool. The volume of the respective stocks was downloaded from Thomson Reuters. Moreover, in order to determine the daily number of transactions, the total number of trades was divided by the number of trading days.

\subsection{Price Discovery Approach}

In order to estimate the market model, we made use of weekly returns for each stock on the corresponding national stock market index from August 2011 to February 2012 (the ban period). The weekly return data for both the individual stocks and the stock market indexes was again downloaded from Thomson Reuters. The reason why we chose a weekly frequency is motivated by previous studies, mainly those of Beber and Pagano (2011) and Bris, Goetzmann and Zhu (2007), that find such frequency to be the optimal balance between noise and information. To test the prediction of price discovery in the study, an estimation of a market model regression was made using EViews. The market model makes use of the formula:

$Y=a+b X$

where $\mathrm{Y}=$ the weekly returns of the stock (dependent variable); and $\mathrm{X}=$ the weekly returns of the national stock market index (independent variable).

Furthermore, the reason why we chose the market model to identify price discovery is due to the fact that the ban should affect price discovery in terms of a firm-specific basis rather than a market-wide informational effect.

\subsection{Stock Price Effect Approach}

The stock prices of 52 banned stocks from FIBS countries were collected from Thomson Reuters, leading to a total of 8,112 observations. On the other hand, 17 stocks from non-FIBS countries were collected, therefore having a total of 2,652 observations. The stock market indexes for both the FIBS and non-FIBS countries were also collected from Thompson Reuters.

One of the main principles why the short selling ban was enacted in August 2011 was to provide effective support to the prices of financial stocks. In order to test whether the previous statement was true or not, the study focuses on the excess returns of the banned stocks in the FIBS and the non-banned stocks in the following European countries: Austria, Germany, Greece and the Netherlands (Non-FIBS).

Excess returns, as defined by Beber and Pagano (2010), is the difference between individual stock returns and the respective country's market index. The stock market 
indexes chosen for the FIBS are CAC40, FTSE MIB, BEL20 and IBEX respectively. The reason why the we chose these respective stocks was due to the fact that the stock index represents the most financially liquid and stable companies in their respective country.

\subsection{Volatility Approach}

Volatility defined as the standard deviation of the return provided by the variable unit per unit over time when the return is expressed as continuous compounding. In this study, only business days are assumed, since volatility tends to be much higher during business days than on non-business days, such as weekends and holidays.

In order to calculate volatility, the study makes use of the Generalised Autoregressive Conditional Heteroskedasticity (GARCH) $(1,1)$ Model, which was proposed by Bollerslev in 1986. The assumption of the GARCH Model is that volatility changes with the passage of time. A further benefit of the GARCH model is that if it is working efficiently, then autocorrelation should be removed.

Furthermore, in order to work out the GARCH $(1,1)$ Model, we use an add-in of Microsoft Excel ${ }^{\circledR}$, NumXL. The study first identified the weekly returns of the respective stock, with the data downloaded from Yahoo! Finance. The next step in determining the GARCH $(1,1)$ Model was to work out the weighted moving average and the exponential moving averages in order for the study to get an idea of the trend of the stock price before, during and after the short selling ban. Furthermore, the study calculates and plots the autocorrelation function (acf) and the partial autocorrelation function (pacf) in order to measure the correlation between the observations, after controlling for observations with intermediate lags. The final step of the calculation of the GARCH $(1,1)$ Model was to run the GARCH Model itself using the weekly percentage returns of the stock.

\subsection{Liquidity Approach}

It is only natural that the average daily number of transactions during times of distress is lower than during normal periods. However in order to counter such an effect the study takes into account both the pre- and post-ban periods, which fall within the European Sovereign Debt Crisis period.

\subsection{Limitations and Assumptions of the Methodology}

The average daily number of transactions analysis may have its restrictions, whereby volatility may not be due to the short selling ban but due to other factors, especially when considering that the analysis is being conducted during the European Sovereign Debt Crisis. The market model only assumes the weekly returns for the stock market index; however the weekly returns for the financial stocks may be 
affected by other factors, which are not portrayed in the market model run by the study.

The excess returns calculation includes the market benchmark indexes for their respective countries. The benchmark indexes however do not represent the whole market but rather a small portion with the most powerful companies in the country. Furthermore, the benchmark index does not only represent financial industry stocks but stocks from the market as a whole, whereas this study focuses only on financial stocks.

The GARCH model operates best under stable market conditions; whereas the research in question is operating during a crisis therefore the market conditions may be fairly unstable.

Although these limitations and assumptions we were still able to give a clear indication of the impacts on the short selling ban on financial markets and whether the impacts were of a short or long-term nature. The study also used several tests that were not used in other papers and analysis of the impacts of short selling bans, hence giving an alternative analysis and viewing of the impacts of the short selling ban.

\section{Findings and Results}

The weekly excess returns for each of the 52 banned stocks grouped by their respective countries and the 17 non-banned stocks grouped altogether are shown in

Table 1. An illustration of the weekly excess returns of the FIBS and non-FIBS countries for the period February 2010 to June 2013.

\begin{tabular}{|c|c|c|c|c|c|}
\hline \multicolumn{6}{|c|}{ EXCESS RETURNS } \\
\hline Period & Belgium & France & Italy & Spain & Non-FIBS \\
\hline Pre-Ban Period & $\begin{array}{l}- \\
1.14595 \%\end{array}$ & $-0.35514 \%$ & $-0.48431 \%$ & $-0.31697 \%$ & $-0.75827 \%$ \\
\hline Ban Period & $\begin{array}{l}- \\
0.02556 \% \\
\end{array}$ & $0.30488 \%$ & $1.00363 \%$ & $0.38407 \%$ & $0.08546 \%$ \\
\hline Post-Ban Period & $\begin{array}{l}- \\
0.08606 \%\end{array}$ & $0.47606 \%$ & $1.01357 \%$ & $-0.14271 \%$ & $-0.00522 \%$ \\
\hline
\end{tabular}

\subsection{Volatility: Belgium}

Pre-Ban Period: The volatility proxy by the exponentially moving average (EWMA) moved smoothly unlike the weekly returns of the Belgian banned financial stocks. Furthermore, it was noted that the volatility proxy by EWMA is more sensitive to positive returns as compared to negative returns. The descriptive statistics of the Belgian financial stocks interpreted that the weekly returns are negatively skewed. However, the skewness of the Belgian financial stocks was not 
significant at the 5\% level of significance. Moreover, the White-noise test did not show any signs of serial correlation between returns. As illustrated in Figure 2, the GARCH model results were calibrated and all the results, those being the Whitenoise, the normal distribution and $\mathrm{ARCH}$, were significant. The GARCH Model estimated volatility to be $5.24 \%$ before the short selling ban began.

Ban Period: The exponentially moving average (EWMA) volatility proxy moved fairly smooth and the study showed that the EWMA is more sensitive to positive returns as compared to negative returns. The descriptive statistics of the Belgian financial stocks showed that the skewness was positive, however the skewness was not significant at the 5\% level. Furthermore, the White-noise test did not show signs of serial correlation between returns.As illustrated in Figure 3 after the GARCH model was calibrated all the results were significant. The volatility during the ban period was $9.58 \%$, which is a lot higher than the pre-ban period.

Post-Ban Period: The exponentially moving average (EWMA) volatility proxy moved fairly smooth and the study showed that the EWMA is more sensitive to positive returns as compared to negative returns. The descriptive statistics of the Belgian financial stocks showed that the skewness was negative, however the skewness was not significant at the 5\% level. Furthermore, the White-noise test did not show signs of serial correlation between returns. As illustrated in Figure 4 after the GARCH model was calibrated all the results were significant. The volatility during the ban period was $5.46 \%$, which is lower compared to the ban period. Furthermore, the results showed that volatility returned to the same approximate value as the pre-ban period values.

\subsection{Volatility: France}

Pre-Ban Period:The volatility proxy by the exponentially moving average (EWMA) moved smoothly unlike the weekly returns of the French banned financial stocks. Furthermore, it was noted that the volatility proxy by EWMA is more sensitive to positive returns as compared to negative returns. The descriptive statistics of the French financial stocks interpreted that the weekly returns are negatively skewed. However, the skewness of the French financial stocks was not significant at the 5\% level of significance. Moreover, the White-noise test did not show any signs of serial correlation between returns. As illustrated in Figure 5, the GARCH model results were calibrated and all the results, those being the White-noise, the normal distribution and ARCH, were significant. The GARCH Model estimated volatility to be $5.53 \%$ before the short selling ban began.

Ban Period: The exponentially moving average (EWMA) volatility proxy moved fairly smooth and the study showed that the EWMA is more sensitive to positive returns as compared to negative returns. The descriptive statistics of the French financial stocks showed that the skewness was positive, however the skewness was not significant at the 5\% level. Furthermore, the White-noise test did not show signs 
of serial correlation between returns. After the GARCH model was calibrated all the results were significant as illustrated in Figure 6. The volatility during the ban period was $7.06 \%$, which is a higher than the pre-ban period.

Post-Ban Period: The exponentially moving average (EWMA) volatility proxy moved fairly smooth and the study showed that the EWMA is more sensitive to positive returns as compared to negative returns. The descriptive statistics of the French financial stocks showed that the skewness was positive, however the skewness was not significant at the 5\% level. Furthermore, the White-noise test did not show signs of serial correlation between returns. After the GARCH model was calibrated all the results were significant as illustrated in Figure 7. The volatility during the ban period was $3.58 \%$, which is a lot lower compared to the ban period.

\subsection{Volatility: Italy}

Pre-Ban Period: The volatility proxy by the exponentially moving average (EWMA) moved smoothly unlike the weekly returns of the Belgian banned financial stocks. Furthermore, it was noted that the volatility proxy by EWMA is more sensitive to positive returns as compared to negative returns. The descriptive statistics of the Italian financial stocks interpreted that the weekly returns are negatively skewed. However, the skewness of the Italian financial stocks was not significant at the 5\% level of significance. Moreover, the White-noise test showed some signs of serial correlation between returns, therefore the GARCH model had to be calibrated. The GARCH Model estimated volatility was $8.40 \%$ before the short selling ban began (Figure 8).

Ban Period: The exponentially moving average (EWMA) volatility proxy moved fairly smooth and the study showed that the EWMA is more sensitive to positive returns as compared to negative returns. The descriptive statistics of the Italian financial stocks showed that the skewness was positive, however the skewness was not significant at the 5\% level. Furthermore, the White-noise test did not show signs of serial correlation between returns. After the GARCH model was calibrated all the results were significant. The volatility during the ban period was $9.47 \%$, which is higher than the pre-ban period implying that volatility increases during the short selling ban period as illustrated in Figure 9.

Post-Ban Period: The exponentially moving average (EWMA) volatility proxy moved fairly smooth and the study showed that the EWMA is more sensitive to positive returns as compared to negative returns. The descriptive statistics of the financial stocks showed that the skewness was positive, however the skewness was not significant at the 5\% level. Furthermore, the White-noise test did not show signs of serial correlation between returns. the volatility during the ban period was $6.26 \%$, which is lower compared to the ban period. Furthermore, it can be concluded that volatility during the short selling ban period increased as compared to periods were the short selling ban was not in place. 


\subsection{Volatility: Spain}

Pre-Ban Period: The volatility proxy by the exponentially moving average (EWMA) moved smoothly unlike the weekly returns of the Spanish banned financial stocks. Furthermore, it was noted that the volatility proxy by EWMA is more sensitive to positive returns as compared to negative returns. The descriptive statistics of the Spanish financial stocks interpreted that the weekly returns are negatively skewed. However, the skewness of the French financial stocks was not significant at the 5\% level of significance. Moreover, the White-noise test did not show any signs of serial correlation between returns. The GARCH model results were calibrated and all the results, those being the White-noise, the normal distribution and $\mathrm{ARCH}$, were significant. The GARCH Model estimated volatility was $2.88 \%$ before the short selling ban began as Figure 11 illustrates.

Ban Period :The exponentially moving average (EWMA) volatility proxy moved fairly smooth and the study showed that the EWMA is more sensitive to positive returns as compared to negative returns. The descriptive statistics of the Spanish financial stocks showed that the skewness was negative, however the skewness was not significant at the 5\% level. Furthermore, the White-noise test did not show signs of serial correlation between returns. After the GARCH model was calibrated all the results were significant. The volatility during the ban period was $3.77 \%$, which is a higher than the pre-ban period implying that the short-selling ban did have a negative effect on volatility (Figure 12).

Post-Ban Period: The exponentially moving average (EWMA) volatility proxy moved fairly smooth and the study showed that the EWMA is more sensitive to positive returns as compared to negative returns. The descriptive statistics of the Spanish financial stocks showed that the skewness was positive, however the skewness was not significant at the 5\% level. Furthermore, the White-noise test did not show signs of serial correlation between returns. After the GARCH model was calibrated all the results were significant. The volatility during the ban period was 4.20\%, as illustrated in Figure 13, which is a higher compared to the ban period.

\subsection{Non-FIBs (Austria, Greece, Germany and the Netherlands)}

Pre-Ban Period: The volatility proxy by the exponentially moving average (EWMA) moved smoothly unlike the weekly returns of the non-FIBS financial stocks. Furthermore, it was noted that the volatility proxy by EWMA is more sensitive to positive returns as compared to negative returns. The descriptive statistics of the non-FIBS financial stocks interpreted that the weekly returns are negatively skewed (-0.74). The skewness of the non-FIBS financial stocks was statistically significant at the 5\% level of significance. Furthermore, the White-noise test was significant and did not show any signs of serial correlation. The GARCH Model estimated volatility was 3.99\% (Figure 14) before the short selling ban began. 
Ban Period: The exponentially moving average (EWMA) volatility proxy moved fairly smooth and the study showed that the EWMA is more sensitive to positive returns as compared to negative returns. The descriptive statistics of the non-FIBS financial stocks showed that the skewness was negative, however the skewness was not significant at the 5\% level. Furthermore, the White-noise test did not show signs of serial correlation between returns. The volatility during the ban period was $7.25 \%$ (Figure 15), which is higher than the pre-ban period implying that volatility did not only increase in FIBS countries but also in non-FIBS countries.

Post-Ban Period: The exponentially moving average (EWMA) volatility proxy moved fairly smooth and the study showed that the EWMA is more sensitive to positive returns as compared to negative returns. The descriptive statistics of the financial stocks showed that the skewness was positive, however the skewness was not significant at the 5\% level. Furthermore, the White-noise test did not show signs of serial correlation between returns. The volatility during the ban period was $3.87 \%$, which is a lot lower than the ban period imposed on the FIBS countries.

\subsection{Price Discovery}

In order to test price discovery, a market model regression was used, where we made use of weekly returns for each stock on the corresponding national stock market index from February 2010 to February 2013.

\subsubsection{Belgium}

Pre-Ban Period: The $\mathrm{R}^{2}$ value of the pre-ban period regression was 0.5227 , indicating that $52.27 \%$ of the total variation in the weekly returns of the financial stocks in Belgium is explained by the variation in the explanatory variable (the Belgian stock index). Furthermore, the Durbin-Watson statistic is very close to two, which implies that there is no serial autocorrelation in the model. The regression stated that on average, a one unit increase in the price of a banned financial stock increased the stock market index of Belgium by 1.701 units.

Ban Period: The $\mathrm{R}^{2}$ value of the pre-ban period regression was 0.3467 , indicating that $34.67 \%$ of the total variation in the weekly returns of the financial stocks in Belgium is explained by the variation in the explanatory variable (the Belgian stock index). Furthermore, the Durbin-Watson statistic is fairly close to two, which implies that there is no serial autocorrelation in the model. The regression stated that on average, a one unit increase in the price of a banned financial stock increased the stock market index of Belgium by 2.04 units.

Post-Ban Period: The $\mathrm{R}^{2}$ value of the pre-ban period regression was 0.1856 , indicating that $18.56 \%$ of the total variation in the weekly returns of the financial stocks in Belgium is explained by the variation in the explanatory variable (the Belgian stock index). Furthermore, the Durbin-Watson statistic is close to two, which implies that there is no serial autocorrelation in the model. The regression 
stated that on average, a one unit increase in the price of a banned financial stock increased the stock market index of Belgium by 1.84 units. The latter shows that price discovery was fairly less after the ban period.

\subsubsection{France}

Pre-Ban Period: The $\mathrm{R}^{2}$ value of the pre-ban period regression was 0.5048 , indicating that $50.48 \%$ of the total variation in the weekly returns of the financial stocks in France is explained by the variation in the explanatory variable (CAC40). Furthermore, the Durbin-Watson statistic is very close to two (1.995), which implies that there is no serial autocorrelation in the model. The regression stated that on average, a one unit increase in the price of the banned financial stocks increased the CAC40 by 1.16 units.

Ban Period:The $\mathrm{R}^{2}$ value of the pre-ban period regression was 0.5234 , indicating that $52.34 \%$ of the total variation in the weekly returns of the financial stocks in France is explained by the variation in the explanatory variable (CAC40). Furthermore, the Durbin-Watson statistic is a bit higher but close to two, which implies that there is no serial autocorrelation in the model. The regression stated that on average, a one unit increase in the price of a banned financial stock increased the stock market index of Belgium by 1.323 units.

Post-Ban Period: The $\mathrm{R}^{2}$ value of the pre-ban period regression was 0.4412 , indicating that $44.12 \%$ of the total variation in the weekly returns of the financial stocks in France is explained by the variation in the explanatory variable (CAC40). Furthermore, the Durbin-Watson statistic is lower but close to two (1.809), which implies that there is no serial autocorrelation in the model. The regression stated that on average, a one unit increase in the price of a banned financial stock increased the stock market index of France by 1.297 units. The latter shows that price discovery was fairly less but relatively close to the ban period's conclusion.

\subsubsection{Italy}

Pre-Ban Period: The $\mathrm{R}^{2}$ value of the pre-ban period regression was 0.3374 , indicating that $33.74 \%$ of the total variation in the weekly returns of the financial stocks in Italy are explained by the variation in the explanatory variable (FTSE MIB). Furthermore, the Durbin-Watson statistic is close to three, which implies that there is some degree of serial autocorrelation in the model.The regression stated that on average, a one unit increase in the price of a banned financial stock increased the stock market index of Italy by 1.024 units.

Ban Period:The $\mathrm{R}^{2}$ value of the pre-ban period regression was 0.3254 , indicating that $32.54 \%$ of the total variation in the weekly returns of the financial stocks in Italy is explained by the variation in the explanatory variable (the FTSE MIB). Furthermore, the Durbin-Watson statistic is approximately 2.67, which implies that there is some degree of serial autocorrelation in the model.The regression stated that 
on average, a one unit increase in the price of a banned financial stock increased the stock market index of Italy by 1.0312 units.

Post-Ban Period:The $\mathrm{R}^{2}$ value of the pre-ban period regression was 0.2857 , indicating that $28.57 \%$ of the total variation in the weekly returns of the financial stocks in Italy is explained by the variation in the explanatory variable. Furthermore, the Durbin-Watson statistic is close to 2.50, which implies that there is some degree of serial autocorrelation in the model. The regression stated that on average, a one unit increase in the price of a banned financial stock increased the stock market index of Belgium by approximately 1 unit. The latter shows that price discovery was fairly less but very similar after the ban period.

\subsubsection{Spain}

Pre-Ban Period: The $\mathrm{R}^{2}$ value of the pre-ban period regression was 0.695 , indicating that $69.50 \%$ of the total variation in the weekly returns of the financial stocks in Spain is explained by the variation in the explanatory variable (IBEX). Furthermore, the Durbin-Watson statistic is fairly close to two (1.704), which implies that there is no serial autocorrelation in the model. The regression stated that on average, a one unit increase in the price of the banned financial stocks increased the IBEX by 0.711 units.

Ban Period: The $\mathrm{R}^{2}$ value of the pre-ban period regression was 0.7837 , indicating that $78.37 \%$ of the total variation in the weekly returns of the financial stocks in Spain is explained by the variation in the explanatory variable (IBEX). Furthermore, the Durbin-Watson statistic is very close to two, which implies that there is no serial autocorrelation in the model. The regression stated that on average, a one unit increase in the price of a banned financial stock increased the stock market index of Belgium by 0.714 units.

Post-Ban Period: The $\mathrm{R}^{2}$ value of the pre-ban period regression was 0.8092 , indicating that $80.92 \%$ of the total variation in the weekly returns of the financial stocks in Spain is explained by the variation in the explanatory variable (IBEX). Furthermore, the Durbin-Watson statistic is a bit higher but close to two (2.11), which implies that there is no serial autocorrelation in the model. The regression stated that on average, a one unit increase in the price of a banned financial stock increased the IBEX by 1.017 units. The latter shows that price discovery was higher than the previous periods.

\subsubsection{Non-FIBS}

Pre-Ban Period: The $\mathrm{R}^{2}$ value of the pre-ban period regression was 0.6491 , indicating that $64.91 \%$ of the total variation in the weekly returns of the financial stocks in non-FIBS countries is explained by the variation in the explanatory variable. Furthermore, the Durbin-Watson statistic is very close to two, which implies that there is no serial autocorrelation in the model. The regression stated that 
on average, a one unit increase in the price of financial stock increased the stock market index of non-FIBS by 1.035 units.

Ban Period: The $\mathrm{R}^{2}$ value of the pre-ban period regression was 0.6901 , indicating that $69.01 \%$ of the total variation in the weekly returns of the financial stocks is explained by the variation in the explanatory variable. Furthermore, the DurbinWatson statistic is lower but rather close to two, which implies that there is no serial autocorrelation in the model. The regression stated that on average, a one unit increase in the price of a non-FIBS financial stock increased the stock market index by 1.292 .

Post-Ban Period: The $\mathrm{R}^{2}$ value of the pre-ban period regression was 0.4216 , indicating that $42.16 \%$ of the total variation in the weekly returns of the financial stocks is explained by the variation in the explanatory variable. Furthermore, the Durbin-Watson statistic is very close to two (1.95), which implies that there is no serial autocorrelation in the model. The regression stated that on average, a one unit increase in the price of non-banned financial stock increased the stock market index by 0.778 units. The latter shows that price discovery was fairly less after the ban period.

\subsection{Stock Price Effect}

The excess returns were calculated in order to conclude whether the short selling ban provided support for the prices of financial stocks. The excess returns for all the respective FIBS and non-FIBS countries are illustrated in Table 1.

\subsubsection{Belgium}

Pre-Ban Period: The pre-ban period's excess returns for the financial stocks was $1.15 \%$, which means that of the pre-ban period's excess returns performed negatively on average.

Ban Period: The ban period's excess returns for the financial stocks was $-0.03 \%$, which showed that the short selling ban had a positive impact on stock prices.

Post-Ban Period: The post-ban period's excess returns for the financial stocks was $0.09 \%$, which showed that the stocks price returns after the ban was lifted remained fairly stable.

\subsubsection{France}

Pre-Ban Period: The pre-ban period's excess returns for the financial stocks was $0.355 \%$, which means that of the pre-ban period's excess returns performed slightly negative on average.

Ban Period: The ban period's excess returns for the financial stocks was $0.305 \%$, which concluded that the short selling ban had a positive impact on the stock price and stocks even achieved a positive return during the ban period. 
Post-Ban Period: The post-ban period's excess returns for the financial stocks was $0.476 \%$, which showed that the stocks price returns after the ban was lifted achieved even higher returns than during the short selling ban period.

\subsubsection{Italy}

Pre-Ban Period: The pre-ban period's excess returns for the financial stocks was $0.484 \%$, which means that of the pre-ban period's excess returns performed negatively on average.

Ban Period: The ban period's excess returns for the financial stocks was $1.004 \%$, which showed that the short selling ban had a very positive impact on stock prices and the short selling ban helped the financial stock prices to stabilise and even achieve positive returns.

Post-Ban Period:The post-ban period's excess returns for the financial stocks was $1.014 \%$, which showed that the stocks price returns after the ban was lifted remained fairly similar as compared to the ban period.

\subsubsection{Spain}

Pre-Ban Period: The pre-ban period's excess returns for the financial stocks was $0.317 \%$, which means that of the pre-ban period's excess returns performed negatively on average.

Ban Period:The ban period's excess returns for the financial stocks was $0.384 \%$, which showed that the short selling ban had a positive impact on stock prices and the short selling ban helped the financial stock prices to stabilise and even achieve positive returns on the Spanish financial stock market.

Post-Ban Period: The post-ban period's excess returns for the financial stocks was $0.143 \%$, which showed that the financial stocks achieved negative returns after the ban was lifted. The latter therefore implied that the short selling ban had a positive impact on the stock returns.

\subsubsection{Non-FIBS}

Pre-Ban Period: The pre-ban period's excess returns for the financial stocks was $0.758 \%$, which means that of the pre-ban period's excess returns performed negatively on average.

Ban Period: The ban period's excess returns for the financial stocks was $0.085 \%$, which showed that the short selling ban also had a positive impact on non-FIBS countries and the impact of the short selling ban had a positive spill over effect on European markets. 
Post-Ban Period:The post-ban period's excess returns for the financial stocks was $0.005 \%$, which showed that the stocks price returns remained fairly stable as compared to the ban period.

\subsection{Liquidity Effect}

The average daily number of transactions helped us to determine how liquidity was effected during the ban period. The average daily number of transactions and the number of days used for the sample period are illustrated on Table 2.

Table 2. The average daily number of transactions estimating the liquidity effect on both FIBS and non-FIBS countries

\begin{tabular}{|l|l|l|l|l|l|l|}
\hline$\underline{\text { Period }}$ & $\begin{array}{l}\text { Number } \\
\text { of } \\
\frac{\text { Trading }}{\text { Days }}\end{array}$ & $\underline{\text { Belgium }}$ & France & $\underline{\text { Italy }}$ & $\underline{\text { Spain }}$ & $\underline{\text { Non-FIBS }}$ \\
\hline $\begin{array}{l}\text { Pre-Ban } \\
\text { Period }\end{array}$ & 240 & $1,287,297$ & $8,560,709$ & $63,713,976$ & $\begin{array}{l}10,184,79 \\
6\end{array}$ & $12,461,315$ \\
\hline $\begin{array}{l}\text { Ban } \\
\text { Period }\end{array}$ & 210 & $1,126,516$ & $5,900,042$ & $47,520,115$ & $3,501,143$ & $10,392,511$ \\
\hline $\begin{array}{l}\text { Post-Ban } \\
\text { Period }\end{array}$ & 240 & $1,558,545$ & $9,306,577$ & $85,467,063$ & $9,756,563$ & $12,610,011$ \\
\hline
\end{tabular}

\subsubsection{Belgium}

Pre-Ban Period

The average daily number of transactions on the banned financial stocks before the ban period was enacted was approximately 1.29 million, which is a lot lower than the 5.014 million average traded on Euronext BEL20.

Ban Period:On the other hand, the ban period's average daily number of transactions was 1.127 million, which shows a lower amount of number of transactions traded and therefore implying lower liquidity.

Post-Ban Period:The post ban period's average daily number of transactions was 1.559 million, which shows a higher amount of transactions than the ban period and also than the pre-ban period. The latter showed that the liquidity increased significantly after the ban period and investors had more confidence to invest in the financial markets.

\subsubsection{France}

Pre-Ban Period: The average daily number of transactions on the banned financial stocks before the ban period was enacted was approximately 8.561 million. 
Ban Period:On the other hand, the ban period's average daily number of transactions was 5.9 million, which shows a significant amount of reduction in the average daily number of transactions traded and a huge loss in market liquidity.

Post-Ban Period: The post ban period's average daily number of transactions was 9.307 million, which again shows that after the ban was lifted the average amount of number of transactions increased after the ban was lifted implying that the short selling ban did have a negative effect on liquidity.

\subsubsection{Italy}

Pre-Ban Period: The average daily number of transactions on the banned financial stocks before the ban period was enacted was approximately 63.714 million.

Ban Period: On the other hand, the ban period's average daily number of transactions was 47.520 million, which shows an alarming amount of lack of transactions traded and a therefore huge loss in market liquidity.

Post-Ban Period: The post ban period's average daily number of transactions was 85.467 million, which again shows a huge increase of transactions after the ban was lifted. The latter implies that the short selling ban reduced significantly market liquidity in the Italian financial stock market.

\subsubsection{Spain}

Pre-Ban Period: The average daily number of transactions on the banned financial stocks before the ban period was enacted was approximately 10.185 million.

Ban Period: On the other hand, the ban period's average daily number of transactions was 3.501 million, which shows a decline in market liquidity during the period the short selling ban was in place.

Post-Ban Period: The post ban period's average daily number of transactions was 9.757 million, which again shows a huge increase of transactions after the ban was lifted. The latter implies that the short selling ban reduced significantly market liquidity in the Spanish financial stock market.

\subsubsection{Non-FIBS}

Pre-Ban Period: The average daily number of transactions on the non-FIBS financial stocks before the ban period was enacted was approximately 12.461 million.

Ban Period: On the other hand, the ban period's average daily number of transactions was 10.392 million, which shows a lower amount of number of transactions traded and therefore implying lower liquidity. 
Post-Ban Period: The post ban period's average daily number of transactions was 12.610 million. The post-ban period's results were fairly similar to the pre-ban period's results.

\subsection{Theoretical and practical implications}

\subsubsection{Volatility}

The FIBS' financial stocks showed relatively higher volatility during the ban period as compared to the pre-ban period, which implies that the short-selling ban did have a negative impact on volatility in the FIBS stock markets. We came to the same conclusions that Bris et al (2003) came to, that is, that short selling restrictions do lead to higher volatility in the markets.

The study analysis of the non-FIBS financial stocks yielded the same conclusions as that of the FIBS, that is, that during the ban period the volatility was higher than before the ban was imposed. The result could be seen from two different point of views. The first point of view being that volatility increased due to other circumstances rather than the short-selling ban, whilst on the other hand, the second conclusion could be that the short-selling ban had a spillover effect on the volatility of other European countries.

Moreover, the study also analysed the period (one year) after the short selling ban was imposed. All the FIBS countries, except for Spain, showed that volatility decreased significantly after the short-selling ban was lifted. We can then conclude that the short-selling ban only had a short-term impact on volatility and there was no permanent impact on the financial stocks' volatility. The reason why Spain had a higher volatility after the ban was lifted could be the huge financial stress it was under during the time period chosen for the study.

\subsubsection{Price Discovery}

The Belgian and French financial stocks were affected by the short-selling ban and price discovery slowed down as compared to the period before the ban was lifted. However, on the other hand, the Spanish and Italian financial stocks were not affected in terms of price discovery when the short-selling ban was imposed. One reason for such results could be that the Spanish and Italian financial stocks were already under huge stressful conditions (lack of demand and supply for the financial stocks), therefore the autocorrelation between the financial stocks and the stock market indexes remained fairly similar.

We find that during the ban period, the price discovery of non-FIBS financial stocks was also affected, even though the effect was minimal. The reason for such, could be that the non-FIBS investors feared that the short-selling ban could be imposed on other European countries, therefore the demand for financial stocks in non-FIBS countries decreased, affecting the price discovery. 
The post-ban short-selling period had similar results for Belgium, France and Italy, where price discovery improved after the ban period was lifted. In the case of Italy, price discovery remained fairly stable over the whole sample period. On the other hand, in the case of Spain, price discovery was affected even further after the ban was lifted. The main reason for such a conclusion could be the "mini-bailout of Bankia" (Financial Times, 2012), which further reduced the demand for Spanish financial stocks. The latter implied that in all cases, apart from in the Spanish financial stocks, the impact of the short-selling ban on price discovery was only temporary.

\subsubsection{Stock Price Effect}

Similar to what Boehmer et al. (2012), concluded in their study, we found that shortselling ban had a positive influence on the financial stock prices of all FIBS countries. Similar conclusions resulted for non-FIBS countries. One of the reasons for such could be that the short-selling ban on FIBS countries helped European markets instil stability and more confidence in the market. The stock prices of the banned financial stocks after the ban was lifted remained fairly stable or showed slight improvements in all FIBS countries. Therefore, we concluded that the shortselling ban did not just have a temporary impact on stock market prices but also had a positive long-term impact on the financial stock prices of the banned stocks.

\subsubsection{Liquidity Effect}

We came to similar conclusions as Beber and Pagano (2011), that the short-selling ban has an adverse effect on market liquidity. The conclusions of the study show that all the FIBS countries suffered heavily in terms of market liquidity during the shortselling ban period. This could be due to the reason that investors fear that more stocks will be banned therefore the market flow stagnates leading to less liquidity.

The analysis of the non-FIBS countries liquidity yielded to the same conclusions as that for the FIBS countries, however the impact on liquidity was far less. These findings could be due to the instability that surrounded the Greek financial crisis, whilst on the other hand, non-FIBS countries, such as Germany and Austria, had a new record in terms of exports (Spiegel, 2013) and a strong economic performance (Deutsche Borse Group, 2012) respectively.

After the ban was lifted, the study concluded that liquidity was higher and at par with the pre-ban period in all FIBS countries. Therefore, the short-selling ban did not have a long-term impact on liquidity but liquidity was only negatively affected during the ban period.

\section{Conclusions}

The short selling ban led to higher volatility in the FIBS countries and also had a spill over effect on non-FIBS countries. Furthermore, with the exception of Spain, 
the impact of the short selling ban on volatility was only deemed to be for a shortterm period.

Although, the short selling ban did not affect Spain and Italy, it slowed down price discovery in Belgium, France and non-FIBS countries. Furthermore, all countries including the non-FIBS countries illustrated a better price discovery position after the ban was lifted; therefore the short selling ban only had a short-term impact on price discovery.

The short selling ban was enacted in order to achieve stability and improve stock market prices. This was achieved for all FIBS countries and also had a positive impact on non-FIBS countries. Furthermore, the impact of the short-selling ban on stock prices was not just temporary but had a long-term positive effect on prices.

One of the main criticisms of the imposition of a short selling ban is that it reduces liquidity and the latter was proved in this research, where liquidity in all FIBS and non-FIBS countries suffered when the short selling ban was imposed. However, the short selling ban only had a short-term impact on liquidity.

As noted, the financial stocks of FIBS countries performed differently in terms of returns prior to the ban. In fact, the financial stocks showed more positive results during the ban period as compared to the period before the ban was enacted. Furthermore, both the FIBS and non-FIBS countries performed in a similar pattern during the short selling ban period, with the exception of price discovery where Spain and Italy performed differently from the other countries analysed during the study.

The short selling-ban affected liquidity, volatility and price discovery negatively, however the impact was only of a short-term nature. On the other hand, stock prices were affected positively by the short selling ban and the impact was that of a longterm nature. The latter conclusions contradicted the findings of Beber and Pagano's (2010), that short selling bans leave stock prices unaffected or has a negative effect.

\section{References:}

Arce, O. and Mayordomo, S. 2014. Short-Sale Constraints and Financial Stability: Evidence from the Spanish Market. Banco de Espana, no. 1410, 1-28.

Autore, D.M, Billingsley, R.S. \& Kovacs, T. 2011. The 2008 short selling ban: Liquidity, dispersion of opinion, and the cross-section of returns of US financial stocks. Journal of Banking \& Finance, 35, 2252-2266.

Battalio, R., Mehran, H. \& Schultz, P. 2010. Market Declines: What is Accomplished by Banning Short-Selling? Federal Reserve Bank of New York Current Issues in Economics and Finance, 18(5), 2-4.

Beber, A. \& Pagano, M. 2011. Short-Selling Bans Around the World: Evidence from the 2007-09 Crisis. Journal of Finance, 68(1), 343-381. 
Boehmer, E., Jones, C.M. \& Zhang, X. 2012. Shacking Short Sellers: The 2008 Short Selling Ban. Edhec Business School, 12-28.

Bris, A., Goetzmann, W.N. \& Zhu, N. 2003. Efficiency and the Bear: Short Sales and Markets around the World. Journal of Finance, 62(3), 1029-1079.

Brooks, C. 2008. A Brief Overview of the Classical Linear Regression Model. Introductary Econometrics for Finance, Second Edition. Cambridge University Press, New York.

Brooks, C. 2010. Panel Data. Introductary Econometrics for Finance, Second Edition. Cambridge University Press, New York.

Chang, E.C, Cheng, J.W. \& Yu, Y. 2007. Short-Sales Constraints and Price Discovery: Evidence from the Hong Kong Market. Journal of Finance, 62(5), 2097-2121.

Deutsche Borse Group 2012. Annual Report 2011, Viewed on 15 April 2015, $\{$ http://deutscheboerse.com/dbg/dispatch/en/binary/dbg_nav/investor_relations/30_ Reports_and_Figures/30_Annual_Reports/20_Archive/Content_Files/Archive/Annu al_Report_2011.pdf\}.

Diether, K., Lee, K.H. \& Werner, I. 2007. Can Short-sellers Predict Returns? Daily Evidence. Fisher College of Business, 12-25.

Fotak, V., Raman, V. \& Yadav, P.K. 2010. Naked Short Selling: The Emperor's New Clothes? Mendoza College of Business, 1-12.

Gagnon, L. \& Witmer, J. 2009. Short Changed? The Market's Reaction to the Short Sale Ban of 2008. Bank of Canada, 3-23.

Handjani, A. 2012. Are short sales beneficial to financial markets? Evidence from Euronext Paris. Proceedings of the Second International Conference on Engaged Management Scholarship, 7-15.

Hull, C. 2012, Volatility. Risk Management and Financial Institutions, Third Edition. Wiley Finance, New Jersey.

Harrison, M.J. \& Kreps, D.M. 1978. Investor Behaviour in a Stock Market with Heterogenous Expectations. The Quarterly Journal of Finance, 92(2), 323-336.

Jones, M.C. \& Lamont, O.A. 2001. Short Sale Constraints and Stock Returns. National Bureau of Economic Research, Working Paper Series.

Kolansinski, A.C., Reed, A.V. \& Thornock, J.R. 2010. Can Short Restrictions Result in More Informed Short Selling? Evidence from 2008 Regulations. AFA 2010 Atlanta Meetings Paper, 1-42.

Lobanova, O, Hamid, S.S.. \& Prakash, AJ. 2009. The Impact of Short-Sale Restrictions on Volatility, Liquidity, and Market Efficiency: The Evidence from the Short-Sale Ban in the US. Florida International University, 1-38.

Mallet, V. \& Johnson, M. 2015. The bank that broke Spain. Viewed on 13 April 2015, \{http://www.ft.com/cms/s/0/d8411cf6-bb89-11e1-90e400144feabdc0.html\#axzz3YgeJA1Lo\}.

Marsh, I.W. \& Payne, R. 2010. Banning Short Sales and Market Quality: The UK's Experience. City University London, Sir John Cass Business School, 1-36.

Mattarocci, G. \& Sampognaro, G. 2009. Financial Crisis and Short Selling: Do Regulatory Bans Really Work? Evidence from the Italian Market. Academy of Accounting and Financial Studies Journal, 15(4).

Pais, A. \& Stork, P.A. 2012. Short-Selling Bans and Contagion Risk. Zicklin-Capco Institute Paper Series in Applied Finance, 35, 109-121.

Saffi, P.A. \& Sigurdsson, K. 2012. Price Efficiency and Short Selling. Review of Finance Studies, 24(3), 821-852.

Scheinkman, J.A. \& Xiong, W. 2003. Overconfidence and Speculative Bubbles, 13th Annual 
Utah Winter Finance Conference. AFA 2003 Washington, D.C. Meetings, 11831218.

Spiegel Online 2013. Booming Sales Beyond Europe: German Exports Seen Hitting New Record in 2012', Viewed on 13 April 2015,

\{http://www.spiegel.de/international/business/new-record-for-german-exportsexpected-for-2012-despite-euro-crisis-a-876296.html \}.

Appendix A - Figures 1 to 31

\begin{tabular}{|c|c|c|c|c|c|c|c|c|c|c|c|c|c|}
\hline $\operatorname{GARCH}(1,1)$ & & & Goodness-of- & & & & Residuals (standardi & & & & & & \\
\hline & Param & Value & LLF & AIC & CHECK & & AVG & STDEV & SKEW & KURTOSIS & S Noise? & Normal? & ARCH? \\
\hline & $\mu$ & -0.01 & 89.82 & -173.64 & 1 & & -0.01 & 1.03 & 0.14 & 0.15 & TRUE & TRUE & FALSE \\
\hline & $a_{0}$ & 0.00 & & & & Target & 0.00 & 1.00 & 0.00 & 0.00 & & & \\
\hline & $a_{1}$ & 0.36 & $\underline{\mathrm{vL}}$ & & & SIG? & FALSE & FALSE & FALSE & FALSE & & & \\
\hline & $\beta_{1}$ & 0.50 & $5.23995 \%$ & & & & & & & & & & \\
\hline
\end{tabular}

Figure 2 - GARCH model results estimating volatility for Belgium before the ban was enacted

\begin{tabular}{|c|c|c|c|c|c|c|c|c|c|c|c|c|c|}
\hline \multicolumn{3}{|l|}{ GARCH $(1,1)$} & \multicolumn{3}{|c|}{ Goodness-of-fit } & & \multicolumn{7}{|c|}{ Residuals (standardized) Analysis } \\
\hline & Param & Value & LLF & AIC & CHECK & & AVG & STDEV & SKEW & KURTOSI & Noise? & Normal & ARCH? \\
\hline & $\mu$ & 0.00 & 25.87 & -45.74 & 1 & & -0.08 & 0.97 & 0.02 & -0.84 & TRUE & TRUE & FALSE \\
\hline & $a_{0}$ & 0.00 & & & & Target & 0.00 & 1.00 & 0.00 & 0.00 & & & \\
\hline & $a_{1}$ & 0.49 & $\underline{\mathrm{v}}$ & & & SIG? & FALSE & FALSE & FALSE & FALSE & & & \\
\hline & $\beta_{1}$ & 0.00 & $9.57749 \%$ & & & & & & & & & & \\
\hline
\end{tabular}

Figure 3 - GARCH model results estimating volatility for Belgium during the ban period

\begin{tabular}{|c|c|c|c|c|c|c|c|c|c|c|c|c|c|}
\hline \multicolumn{3}{|l|}{ GARCH $(1,1)$} & \multicolumn{3}{|l|}{ Goodness-of-fit } & & \multicolumn{7}{|c|}{ Residuals (standardized) Analysis } \\
\hline & Param & Value & LF & AIC & CHECK & & AVG & STDEV & SKEW & KURTOSIS & Noise? & Normal? & ARCH? \\
\hline & $\alpha_{0}$ & 0.00 & & & & Target & 0.00 & 1.00 & 0.00 & 0.00 & & & \\
\hline & $\alpha_{1}$ & 0.00 & $\underline{\mathrm{v}}$ & & & sig? & FALSE & FALSE & FALSE & FALSE & & & \\
\hline
\end{tabular}

Figure 4-GARCH model's results estimating volatility for Belgium after the ban was lifted

\begin{tabular}{|c|c|c|c|c|c|c|c|c|c|c|c|c|c|}
\hline $\operatorname{GARCH}(1,1)$ & & & \multicolumn{3}{|c|}{ Goodness-of-fit } & & \multicolumn{7}{|c|}{ Residuals (standardized) Analysis } \\
\hline & $\mu$ & 0.00 & 112.01 & -218.02 & 1 & & -0.13 & 0.98 & 0.11 & -0.63 & TRUE & TRUE & $\overline{\text { FALSE }}$ \\
\hline & $\alpha_{0}$ & 0.00 & & & & Target & 0.00 & 1.00 & 0.00 & 0.00 & & & \\
\hline & $a_{1}$ & 0.57 & $\underline{\mathrm{VL}}$ & & & SIG? & FALSE & FALSE & FALSE & FALSE & & & \\
\hline
\end{tabular}

Figure 5 - GARCH model's results estimating volatility for France before the ban was enacted

\begin{tabular}{|c|c|c|c|c|c|c|c|c|c|c|c|c|c|}
\hline \multicolumn{3}{|l|}{$\operatorname{GARCH}(1,1)$} & \multicolumn{3}{|l|}{ Goodness-of-fit } & & \multicolumn{7}{|c|}{ Residuals (standardized) Analysis } \\
\hline & Param & Value & LLF & $\mathrm{AIC}$ & CHECK & & AVG & STDEV & SKEW & KURTOSIS & Noise? & Normal? & ARCH? \\
\hline & $\alpha_{0}$ & 0.00 & & & & Target & 0.00 & 1.00 & 0.00 & 0.00 & & & \\
\hline & $\alpha_{1}$ & 0.00 & $\underline{\mathrm{VL}}$ & & & SIG? & FALSE & FALSE & FALSE & FALSE & & & \\
\hline
\end{tabular}

Figure 6-GARCH model's results estimating volatility for France during the ban period

\begin{tabular}{|c|c|c|c|c|c|c|c|c|c|c|c|c|}
\hline \multicolumn{3}{|l|}{ GARCH $(1,1)$} & \multicolumn{3}{|c|}{ Goodness-of-fit } & & \multicolumn{6}{|l|}{ Residuals (standardized) Analysis } \\
\hline & Param & Value & LLF & AIC & CHECK & & AVG & STDEV & SKEW & KURTOSIS & Noise? & Normal? ARCH? \\
\hline & $\alpha_{0}$ & 0.00 & & & & Target & 0.00 & 1.00 & 0.00 & 0.00 & & \\
\hline & $\beta_{1}$ & 0.00 & $3.58262 \%$ & & & & & & & & & \\
\hline
\end{tabular}


Figure 7 - GARCH model's results estimating volatility for France after the ban was lifted

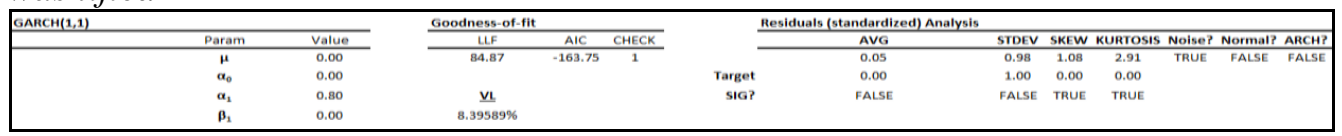

Figure 8-GARCH model's results estimating volatility for Italy before the ban was enacted

\begin{tabular}{|c|c|c|c|c|c|c|c|c|c|c|c|c|}
\hline \multicolumn{3}{|l|}{$\operatorname{GARCH}(1,1)$} & \multicolumn{3}{|l|}{ Goodness-of-fit } & & \multicolumn{6}{|c|}{ Residuals (standardized) Analysis } \\
\hline & Param & Value & LLF & AIC & CHECK & & AVG & STDEV & SKEW K & KURTOSIS & Noise? & Normal? ARCH? \\
\hline & $\mu$ & 0.01 & 25.01 & -44.03 & 1 & & -0.01 & 1.00 & 1.45 & 4.03 & TRUE & FALSE FALSE \\
\hline & $a_{0}$ & 0.01 & & & & Target & 0.00 & 1.00 & 0.00 & 0.00 & & \\
\hline & $a_{1}$ & 0.17 & $\underline{\mathrm{VL}}$ & & & SIG? & FALSE & FALSE & TRUE & TRUE & & \\
\hline & $\beta_{1}$ & 0.00 & $9.46654 \%$ & & & & & & & & & \\
\hline
\end{tabular}

Figure 9 - GARCH model's results estimating volatility for Italy during the ban period

\begin{tabular}{|c|c|c|c|c|c|c|c|c|c|c|c|c|}
\hline \multicolumn{3}{|l|}{ SARCH $(1,1)$} & \multicolumn{3}{|c|}{ Goodness-of-fit } & & \multicolumn{6}{|c|}{ Residuals (standardized) Analysis } \\
\hline & Param & Value & LLF & AIC & CHECK & & AVG & STDEV & SKEW & KURTOSIS & S Noise? & Normal? ARCH? \\
\hline & $\mu$ & 0.01 & 74.78 & -143.56 & 1 & & 0.01 & 1.01 & 0.66 & 1.86 & TRUE & FALSE FALSE \\
\hline & $a_{1}$ & 0.15 & $\underline{\mathrm{VL}}$ & & & SIG? & FALSE & FALSE & FALSE & TRUE & & \\
\hline & $\beta_{1}$ & 0.00 & $6.26104 \%$ & & & & & & & & & \\
\hline
\end{tabular}

Figure 10 - GARCH model's results estimating volatility for Italy after the ban was lifted

\begin{tabular}{|c|c|c|c|c|c|c|c|c|c|c|c|c|}
\hline \multicolumn{3}{|l|}{$\operatorname{GARCH}(1,1)$} & \multicolumn{3}{|l|}{ Goodness-of-fit } & \multicolumn{7}{|c|}{ Residuals (standardized) Analysis } \\
\hline & Param & Value & LLF & AIC & CHECK & & AVG & STDEV & SKEW & KURTOSIS & Noise? & Normal? ARCH? \\
\hline & $\mu$ & 0.00 & 121.06 & -236.12 & 1 & & -0.01 & 0.95 & -0.01 & -0.06 & TRUE & TRUE FALSE \\
\hline & $a_{0}$ & 0.00 & & & & Target & 0.00 & 1.00 & 0.00 & 0.00 & & \\
\hline & $\alpha_{1}$ & 0.16 & $\underline{\mathrm{VL}}$ & & & SIG? & FALSE & FALSE & FALSE & FALSE & & \\
\hline & $\beta_{1}$ & 0.16 & $2.88176 \%$ & & & & & & & & & \\
\hline
\end{tabular}

Figure 11 - GARCH model's results estimating volatility for Spain before the ban was enacted

\begin{tabular}{|c|c|c|c|c|c|c|c|c|c|c|c|c|c|}
\hline GARCH(1,1) & & & Goodness-of-f & & & & Residuals (standardized) Analysis & & & & & & \\
\hline & Param & Value & LLF & AIC & CHECK & & AVG & STDEV & SKEW & KURTOSIS & Noise? & Normal? & ARCH? \\
\hline & $\alpha_{0}$ & 0.00 & & & & Target & 0.00 & 1.00 & 0.00 & 0.00 & & & \\
\hline & $\beta_{1}$ & 0.00 & $3.76972 \%$ & & & & & & & & & & \\
\hline
\end{tabular}

Figure 12 - GARCH model's results estimating volatility for Spain during the ban period

\begin{tabular}{|c|c|c|c|c|c|c|c|c|c|c|c|c|c|}
\hline \multirow{2}{*}{$\operatorname{GARCH}(\mathbf{1}, \mathbf{1})$} & & & \multicolumn{3}{|c|}{ Goodness-of-fit } & & \multicolumn{7}{|c|}{ Residuals (standardized) Analysis } \\
\hline & Param & Value & LLF & AIC & CHECK & & AVG & STDEV & SKEW & KURTOSIS & Noise? & Normal? & ARCH? \\
\hline & $\mu$ & 0.00 & 94.64 & -183.27 & 1 & & 0.00 & 1.00 & 0.26 & -0.40 & TRUE & TRUE & FALSE \\
\hline & $\alpha_{0}$ & 0.00 & & & & Target & 0.00 & 1.00 & 0.00 & 0.00 & & & \\
\hline & $\alpha_{1}$ & 0.02 & vL & & & SIG? & FALSE & FALSE & FALSE & FALSE & & & \\
\hline & $\beta_{1}$ & 0.02 & $4.19850 \%$ & & & & & & & & & & \\
\hline
\end{tabular}

Figure 13 - GARCH's model results estimating volatility for Spain after the ban was lifted 


\begin{tabular}{|c|c|c|c|c|c|c|c|c|c|c|c|c|}
\hline $\operatorname{GARCH}(\mathbf{1}, \mathbf{1})$ & & & Goodness-of-f & & & & $\begin{array}{l}\text { Residuals (standardized) Analysis } \\
\end{array}$ & & & & & \\
\hline & Param & Value & LLF & AIC & CHECK & & AVG & STDEV & SKEW K & KURTOSIS & Noise? & Normal? ARCH? \\
\hline & $\alpha_{0}$ & 0.00 & & & & Target & 0.00 & 1.00 & 0.00 & 0.00 & & \\
\hline & $\alpha_{1}$ & 0.10 & $\underline{\mathrm{VL}}$ & & & SIG? & FALSE & FALSE & FALSE & TRUE & & \\
\hline
\end{tabular}

Figure 14 - GARCH model results estimating volatility for Non-FIBS before the ban was lifted

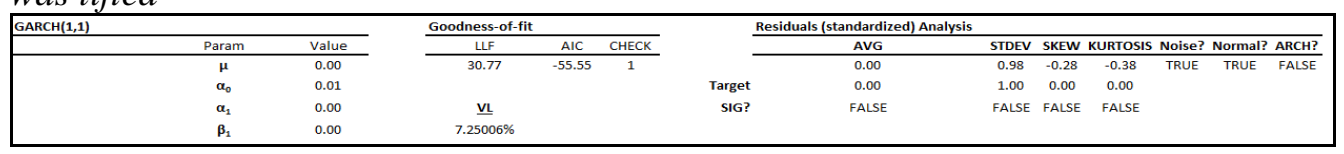

Figure 15 - GARCH model results estimating volatility for non-FIBS during the ban period

\begin{tabular}{|c|c|c|c|c|c|c|c|c|c|c|c|c|c|}
\hline \multicolumn{3}{|l|}{ GARCH(1,1) } & \multicolumn{3}{|c|}{ Goodness-of-fit } & & \multicolumn{7}{|c|}{ Residuals (standardized) Analysis } \\
\hline & $\mu$ & 0.00 & 98.95 & -191.90 & 1 & & 0.00 & 1.02 & 0.46 & -0.03 & TRUE & TRUE & FALSE \\
\hline & $\alpha_{0}$ & 0.00 & & & & Target & 0.00 & 1.00 & 0.00 & 0.00 & & & \\
\hline & $\alpha_{1}$ & 0.00 & $\underline{\mathrm{VL}}$ & & & SIG? & FALSE & FALSE & FALSE & FALSE & & & \\
\hline
\end{tabular}

Figure 16-GARCH model results estimating volatility for non-FIBS after the ban was lifted

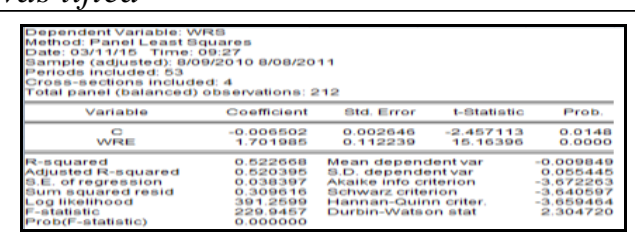

Figure 17 - Market model results estimating price discovery for Belgium before the ban was enacted

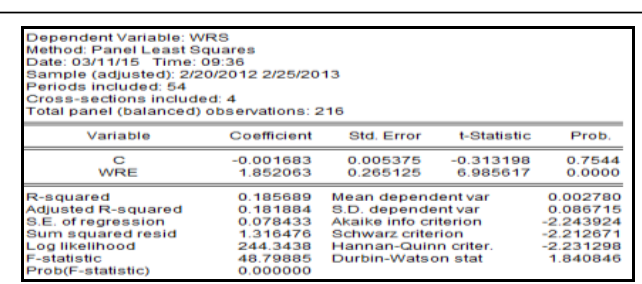

Figure 19 - Market model results estimating price discovery for Belgium after the ban was lifted

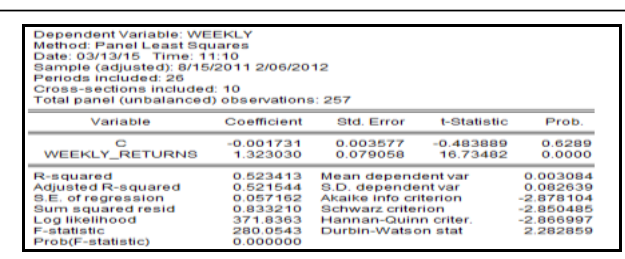

Figure 21 - Market model results estimating price discovery for France during the ban period

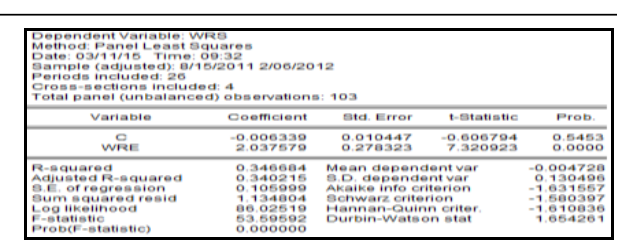

Figure 18 - Market model results estimating price discovery for Belgium during the ban period

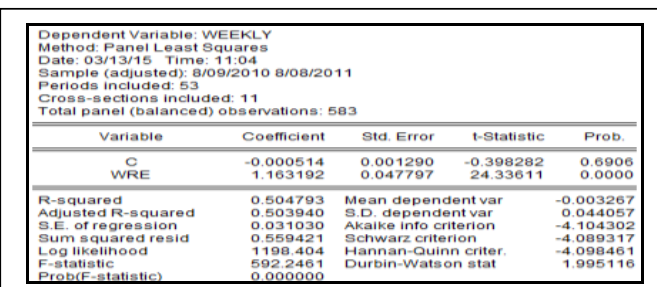

Figure 20 - Market model results estimating price discovery for France before the ban was enacted

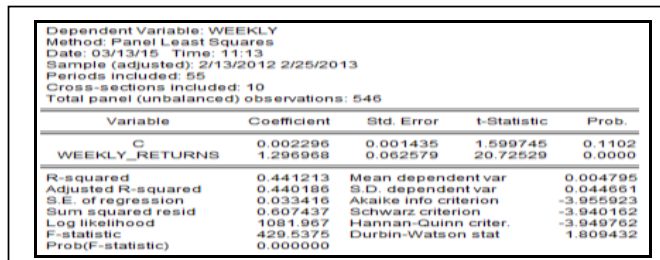

Figure 22 - Market model results estimating price discovery for France after the ban was lifted 


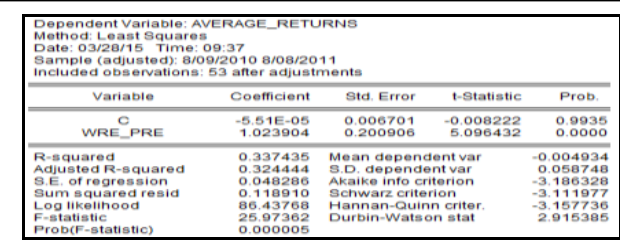

Figure 23 - Market model results estimating price discovery for Italy before the ban was enacted

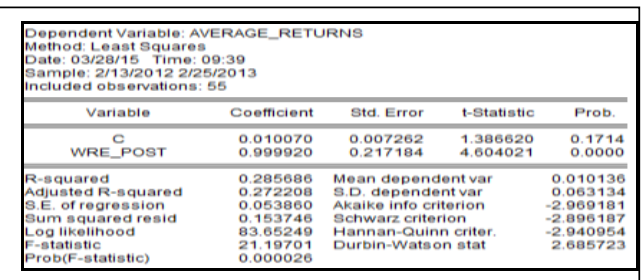

Figure 25 - Market model estimating price discovery for Italy after the ban was lifted

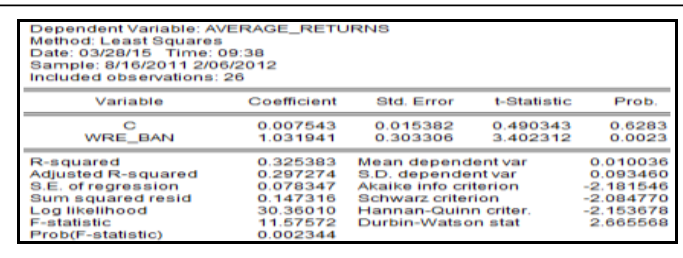

Figure 24 - Market model results estimating price discovery for Italy during the ban period

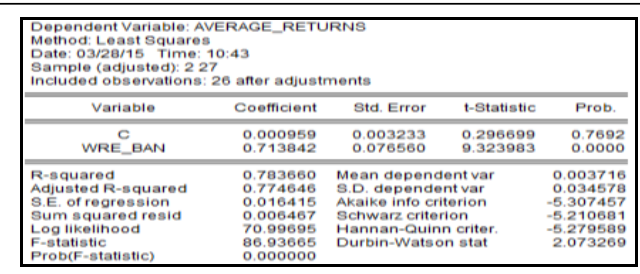

Figure 27 - Market model estimating price discovery for Spain during the ban period

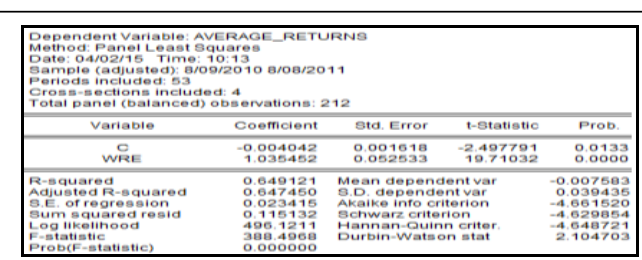

Figure 29 - Market model estimating price discovery for non-FIBS before the ban was enacted

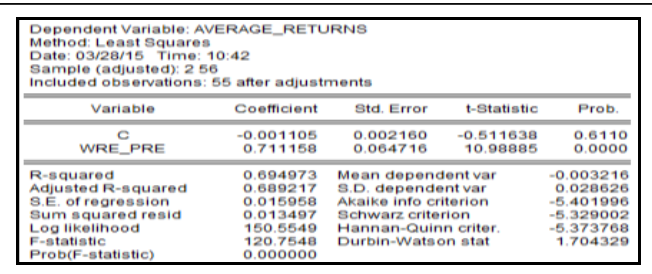

Figure 26 - Market model estimating price discovery for Spain before the ban was enacted

Figure 28 - Market model estimating price discovery for Spain after the ban was lifted

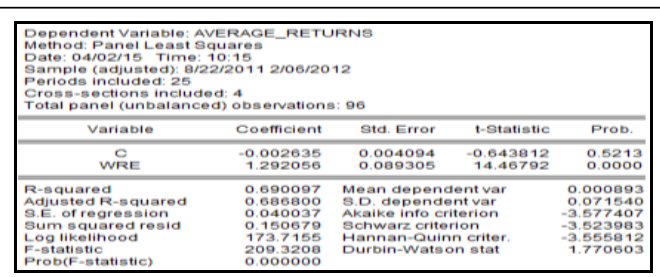

Figure 30 - Market model estimating price discovery for non-FIBS during the ban period 


\begin{tabular}{|c|c|c|c|c|}
\hline \multicolumn{5}{|c|}{$\begin{array}{l}\text { Dependent Variable: AVERAGE_RETURNS } \\
\text { Method: Panel Least Squares } \\
\text { Date: } 04 / 02 / 15 \text { Time: } 10: 20 \\
\text { Sample (adjusted): } 2 / 20 / 2012 \text { 2/25/2013 } \\
\text { Periods included: } 54 \\
\text { Cross-sections included: } 4 \\
\text { Total panel (balanced) observations: } 216\end{array}$} \\
\hline Variable & Coefficient & Std. Error & $\mathrm{t}$-Statistic & Prob. \\
\hline $\begin{array}{c}\mathrm{C} \\
\text { WRE }\end{array}$ & $\begin{array}{r}-0.002108 \\
0.778101\end{array}$ & $\begin{array}{l}0.002040 \\
0.062298\end{array}$ & $\begin{array}{r}-1.033265 \\
12.48999\end{array}$ & $\begin{array}{l}0.3026 \\
0.0000\end{array}$ \\
\hline $\begin{array}{l}\text { R-squared } \\
\text { Adjusted R-squared } \\
\text { S.E. of regression } \\
\text { Sum squared resid } \\
\text { Log likelihood } \\
\text { F-statistic } \\
\text { Prob(F-statistic) }\end{array}$ & $\begin{array}{l}0.421621 \\
0.418919 \\
0.029887 \\
0.191152 \\
452.7453 \\
155.9998 \\
0.000000\end{array}$ & \multicolumn{2}{|c|}{$\begin{array}{l}\text { Mean dependent var } \\
\text { S.D. dependent var } \\
\text { Akaike info criterion } \\
\text { Schwarz criterion } \\
\text { Hannan-Quinn criter. } \\
\text { Durbin-Watson stat }\end{array}$} & $\begin{array}{r}-5.22 \mathrm{E}-05 \\
0.039207 \\
-4.173568 \\
-4.142315 \\
-4.160942 \\
1.950583\end{array}$ \\
\hline
\end{tabular}

Figure 31 - Market model estimating price discovery for non-FIBS after the ban was lifted

Appendix B - DEFINITION OF GARCH $(1,1) \mathrm{MODEL}$

GARCH MODEL

$\sigma_{n}^{2}=\gamma V_{L}+\alpha u_{n-1}^{2}+\beta \sigma_{n-1}^{2}$

$\sigma_{n}^{2}-$ GARCH Model

$V_{L}$ - Long-Run Average Variance Rate

$\gamma$ - Weight Assigned to $V_{L}$

$\alpha$ - Weight Assigned to $u_{n-1}^{2}$

$\beta-$ Weight Assigned to $\sigma_{n-1}^{2}$

$\gamma+\alpha+\beta=1$

Appendix C-FIBS AND NON-FIBS' CONSTITUENTS

\begin{tabular}{|l|l|l|l|}
\hline FIBS & & & \\
\hline BELGIUM & FRANCE & ITALY & ITALY \\
\hline Ageas SA_NV & April Group & $\begin{array}{l}\text { Assicurazioni } \\
\text { Generali }\end{array}$ & Banca Ifis \\
\hline Dexia SA & Credit Agricole & $\begin{array}{l}\text { Banca Popolare } \\
\text { dell'Etruria }\end{array}$ & Banco di Sardegna \\
\hline KBC Ancora & AXA & Intesa Sanpaolo & Ubi banca \\
\hline & Euler Hermes & Azimut Holding & Banca Intermobiliare \\
\hline & BNP Paribas & $\begin{array}{l}\text { Banca Popolare di } \\
\text { Milano }\end{array}$ & Banco Popolare \\
\hline & Natixis & Mediobanca & UniCredit \\
\hline & CIC & Banca Carige & Banca Monte dei Paschi \\
\hline & SCOR & Banca Popolare di & Credito Emiliano \\
\hline
\end{tabular}




\begin{tabular}{|l|l|l|l|}
\hline & & Sondrio & \\
\hline & CNP Assurance & Mediolanum & Unipol \\
\hline & Societe Generale & Banca Finnat & $\begin{array}{l}\text { Banca Popolare } \\
\text { dell'Emilia Romagnia }\end{array}$ \\
\hline & & Banca Profilo & Credito Valtellinese \\
\hline & & $\begin{array}{l}\text { Milano } \\
\text { Assicurazioni }\end{array}$ & \\
\hline & Banca Generali & \\
\hline & & $\begin{array}{l}\text { Banca di Desio e } \\
\text { Brienza }\end{array}$ & \\
\hline & & $\begin{array}{l}\text { Societa Cattolica di } \\
\text { Ass }\end{array}$ & \\
\hline
\end{tabular}

\begin{tabular}{|l|l|l|l|}
\hline NON-FIBS & & & \\
\hline AUSTRIA & GERMANY & GREECE & NETHERLANDS \\
\hline Erste Group Bank & Aareal Bank AG & Alpha Bank AE & Aegon \\
\hline Raiffeisen Bank & Allianz SE & Hellenic Exchanges & Delta Lloyd NV \\
\hline $\begin{array}{l}\text { Vienna Insurance } \\
\text { Group }\end{array}$ & Commerzbank AG & Marfin Investment & ING Groep NV \\
\hline & Deutsche Bank AG & Piraeus Bank SA & Kuka AG \\
\hline & & & Nanostart AG \\
\hline & & & MLP AG \\
\hline
\end{tabular}

